\title{
Allogeneic hematopoietic stem cell transplantation in children with primary immunodeficiencies: Hospital Israelita Albert Einstein experience
}

\author{
Transplante alogênico de células-tronco hematopoéticas em crianças com imunodeficiências \\ primárias: a experiência do Hospital Israelita Albert Einstein
}

Juliana Folloni Fernandes ${ }^{1}$, Fabio Rodrigues Kerbauy ${ }^{2}$, Andreza Alice Feitosa Ribeiro ${ }^{3}$, Jose Mauro Kutner ${ }^{4}$, Luis Fernando Aranha Camargo ${ }^{5}$, Adalberto Stape ${ }^{6}$, Eduardo Juan Troster ${ }^{7}$, Gabriele Zamperlini-Netto ${ }^{8}$, Alessandra Milani Prandini de Azambuja ${ }^{9}$, Bruna Carvalho ${ }^{9}$, Mayra de Barros Dorna ${ }^{10}$, Marluce dos Santos Vilela ${ }^{11}$, Cristina Miuki Abe Jacob ${ }^{10}$, Beatriz Tavares Costa-Carvalho ${ }^{12}$, Jose Marcos Cunha ${ }^{13}$, Magda Maria Carneiro-Sampaio ${ }^{10}$, Nelson Hamerschlak ${ }^{14}$

\begin{abstract}
Objective: To report the experience of a tertiary care hospital with allogeneic hematopoietic stem cell transplantation in children with primary immunodeficiencies. Methods: Seven patients with primary immunodeficiencies (severe combined immunodeficiency: $\mathrm{n}=2$; combined immunodeficiency: $\mathrm{n}=1$; chronic granulomatous disease: $\mathrm{n}=1$; hyper-IgM syndrome: $\mathrm{n}=2$; and IPEX syndrome: $\mathrm{n}=1$ ) who underwent eight hematopoietic stem cell transplants (HSCT) in a single center, from 2007 to 2010, were studied. Results: Two patients received transplants from HLA-identical siblings; the other six transplants were done with unrelated donors (bone marrow: $\mathrm{n}$ $=1$; cord blood: $\mathrm{n}=5$ ). All patients had pre-existing infections
\end{abstract}

before hematopoietic stem cell transplants. One patient received only anti-thymocyte globulin prior to transplant, three transplants were done with reduced intensity conditioning regimens and four transplants were done after myeloablative therapy. Two patients were not evaluable for engraftment due to early death. Three patients engrafted, two had primary graft failure and one received a second transplant with posterior engraftment. Two patients died of regimen related toxicity (hepatic sinusoidal obstruction syndrome); one patient died of progressive respiratory failure due to Parainfluenza infection diagnosed prior to transplant. Four patients are alive and well from 60 days to 14 months after transplant. Conclusion: Patients' status prior to transplant is the most important risk factor on the outcome

\footnotetext{
Study carried out at the Hospital Israelita Albert Einstein- HIAE, São Paulo (SP), Brazil.

${ }^{1}$ Hematology and Bone Marrow Transplantation, Hospital Israelita Albert Einstein - HIAE - São Paulo (SP), Brazil. Children's Institute of Hospital da Clínicas of Medical College at Universidade de São Paulo - USP, São Paulo (SP), Brazil.

${ }^{2}$ Hematology and Bone Marrow Transplantation, Hospital Israelita Albert Einstein - HIAE - São Paulo (SP), Brazil.

${ }^{3}$ Hemotherapy, Hospital Israelita Albert Einstein - HIAE - São Paulo (SP), Brazil; Hematology and Bone Marrow Transplantation, Hospital Israelita Albert Einstein - HIAE - São Paulo (SP), Brazil.

${ }^{4}$ Blood Bank, Hospital Israelita Albert Einstein - HIAE - São Paulo (SP), Brazil; Hematology and Bone Marrow Transplantation, Hospital Albert Eisntein - HIAE - São Paulo (SP), Brazil.

${ }^{5}$ Clinical Trials Center of Instituto Israelita de Ensino e Pesquisa Albert Eisntein - IIEPAE - São Paulo (SP), Brazil.

${ }^{6}$ Pediatrics, Hospital Israelita Albert Einstein - HIAE - São Paulo (SP), Brazil.

${ }^{7}$ Pediatrics, Hospital Israelita Albert Einstein - HIAE - São Paulo (SP), Brazil; Institute for Treament of Cancer in Children - Children's Institute of Hospital das Clinicas of Medical College at Universidade de São Paulo - USP - São Paulo (SP), Brazil.

${ }^{8}$ Pediatric Oncology, Hospital Israelita Albert Einstein - HIAE - São Paulo (SP), Brazil; Hematology and Bone Marrow Transplantation, Hospital Israelita Albert Einstein - HIAE - São Paulo - Brazil.

${ }^{9}$ Hospital Israelita Albert Einstein - HIAE - São Paulo (SP), Brazil; Children's Institute of Hospital da Clínicas of Medial College at Universidade De São Paulo - USP - São Paulo (SP), Brazil.

${ }^{10}$ Children's Institute of Hospital das Clínicas of Medical Colege at Unversidade de São Paulo - USP- São Paulo (SP), Brazil.

${ }^{11}$ Medical Science College at Universidade Estadual de Campinas - UNICAMP - São Paulo (SP), Brazil.

${ }^{12}$ Discipline of Allergy, Clinical immunology and Rheumatology of department of Pediatrics at Universidade Federal de São Paulo - UNIFESP - São Paulo (SP), Brazil

${ }^{13}$ Universidade Federal do Rio de Janeiro - UFRJ - Rio de Janeiro (RJ), Brazil.

${ }^{14}$ Hematology and Bone Marrow Transplantation, Hospital Israelita Albert Einstein - HIAE - São Paulo (SP), Brazil.

Corresponding author: Juliana Folloni Fernandes - Unidade de Hematologia e Transplante de Médula Óssea do Hospital Israelita Albert Einstein - Avenida Albert Einstein, 627/701 - Morumbi - CEP 05409-011 - São Paulo (SP), Brasil - Tel.: (11) 2151-3203 - e-mail: jfolloni@einstein.br

Received on Mar 6, 2011 - Accepted on Apr 13, 2011

The authors declare there is no conflict of interest.
} 
of hematopoietic stem cell transplants in the treatment of these diseases. Early diagnosis and the possibility of a faster referral of these patients for treatment in reference centers may substantially improve their survival and quality of life.

Keywords: Immunologic deficiency syndromes; Hematopoietic stem cell transplantation; Child

\section{RESUMO}

Objetivo: Relatar a experiência de um hospital terciário no tratamento de pacientes pediátricos com imunodeficiências primárias com transplante de células-tronco hematopoéticas. Métodos: De 2007 a 2010, foram realizados oito transplantes em sete pacientes pediátricos com imunodeficiências primárias: imunodeficiência combinada grave $(n=2)$; imunodeficiência combinada ( $\mathrm{n}=1)$; doença granulomatosa crônica $(\mathrm{n}=1)$; síndrome hiper-IgM $(n=2)$; síndrome IPEX $(n=1)$. Resultados: Dois pacientes foram transplantados com medula óssea de irmãos HLA-idênticos; seis transplantes foram feitos com doadores não aparentados (medula óssea: $\mathrm{n}=1$; sangue de cordão umbilical: $\mathrm{n}=5$ ). Todos os pacientes haviam tido episódios de infecção grave previamente ao tratamento. Um paciente recebeu apenas globulina antitimocítica antes do transplante de células-tronco hematopoéticas, três transplantes foram feitos com quimioterapia de intensidade reduzida e quatro após quimioterapia mieloablativa. Dois pacientes morreram precocemente e não foram avaliados em relação à enxertia. Três pacientes tiveram enxertia completa, dois evoluíram com falha primária de pega, um deles recebeu um segundo transplante com pega do enxerto. Dois pacientes morreram de toxicidade do transplante (síndrome da obstrução sinusoidal hepática), um paciente morreu de insuficiência respiratória por infecção por parainfluenza já existente antes do transplante. Quatro pacientes estão vivos e bem entre 60 dias e 14 meses após o transplante. Conclusão: A condição do paciente ao transplante é o fator mais importante no sucesso do tratamento. 0 diagnóstico precoce dos pacientes e a possibilidade de encaminhá-los mais rapidamente para tratamento em centros de referência podem melhorar substancialmente a sobrevida e a qualidade de vida deles.

Descritores: Síndromes de imunodeficiência; Transplante de célulastronco hematopoéticas; Criança

\section{INTRODUCTION}

Primary immunodeficiencies (PID) are inherited disorders affecting distinct components of the innate or adaptive immune systems that commonly lead to lethal complications. More than 150 different types of diseases have been described, with more than 120 different causative genes being already diagnosed ${ }^{(1)}$. The most severe disorders, such as severe combined immunodeficiencies (SCID), are generally fatal in the first year of life if untreated. Since the first transplants performed in 1968, leading to the cure of a patient with X-linked SCID and a patient with Wiskott-Aldrich syndrome ${ }^{(2-3)}$, hematopoietic stem cell transplantation (HSCT) has been the only curative treatment for a large variety of these diseases.

Survival after HSCT has improved over time. Better development of HLA typing techniques improved donor selection; better infection prophylaxis and treatment, as well as better management of graft versus host disease (GVHD) have reduced disease and transplant-related complications $^{(4)}$. With the use of alternative types of donor such as unrelated marrow donors, unrelated umbilical cord blood units (UCB) and mismatched related (haploidentical) family donors, the possibility to perform stem cell transplantation has been extended to virtually all patients with PID, and patients can be treated faster ${ }^{(5-7)}$. We present here our experience in the treatment of PID with hematopoietic stem cell transplantation.

\section{OBJECTIVE}

To report the experience of a tertiary care hospital in allogeneic hematopoietic stem cell transplantation in children with primary immunodeficiencies.

\section{METHODS}

The study was carried out at Hospital Israelita Albert Einstein (HIAE), which is a private tertiary care hospital in the city of São Paulo (SP), Brazil.

\section{Patients and donors characteristics}

From 2007 to 2010, seven patients with different types of PID underwent eight HSCT in our unit. Table 1 shows patients, donors and transplant characteristics. Patients aged from 1 to 6 years and six were males. The diagnoses were: severe combined immunodeficiency $(\mathrm{n}=2)$; combined immunodeficiency $(\mathrm{n}=1)$; hyperIgM syndrome $(\mathrm{n}=2)$; IPEX (immune dysregulation, polyendocrinopathy, enteropathy, X-linked) syndrome $(\mathrm{n}=1)$; and chronic granulomatous disease $(\mathrm{n}=1)$. All patients had pre-existing infections (Table 1). Donor sources were: bone marrow from HLA identical sibling $(\mathrm{n}=2)$; bone marrow from matched unrelated donor $(\mathrm{n}=1)$ and $\mathrm{UCB}(\mathrm{n}=5)$. Unrelated marrow was HLA matched 10 out of 10 (class I and class II high resolution). All UCB units were 5 out of 6 HLA matched (considering class I (A, B) low resolution and class II (DRB1) high resolution).

\section{Conditioning regimens and GVHD prophylaxis}

One patient with SCID received only antithymocyte globulin (ATG) before transplant (due 


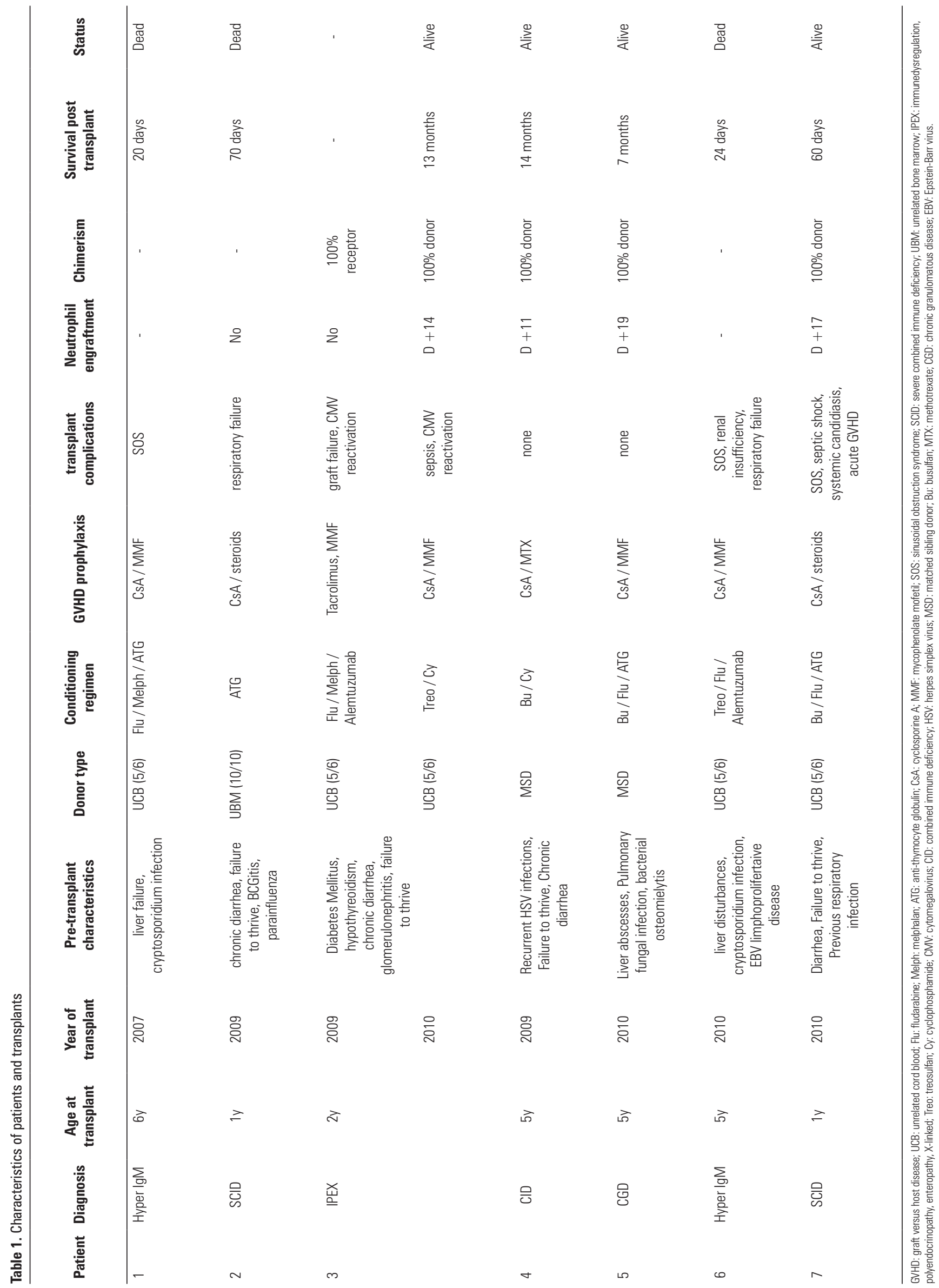


to bad performance status prior to transplant). Two patients received transplants with reduced intensity conditioning (fludarabine and melphalan, with ATG or alemtuzumab). The remaining six transplants received full myeloablative conditioning regimens with busulfan $(\mathrm{Bu})$ or treosulfan and cyclophosphamide or fludarabine, with or without ATG. Two patients (Patient 5 and 7) had their Bu doses adjusted according to pharmacokinetics study after the first $\mathrm{Bu}$ dose. GVHD prophylaxis was assured by cyclosporine A in all eight transplants, associated with mycophenolate mofetil, methotrexate or steroids.

\section{Supportive therapy}

All patients were transplanted in rooms with HEPA filters and positive air pressure, at least until neutrophil recovery (neutrophil counts over $0,5 \times 10 / \mathrm{L}$ for 3 consecutive days). All patients transplanted with UCB units received granulocyte colony-stimulating factor (G-CSF) from day 1 until neutrophil recovery. Antimicrobial prophylaxis during transplantation consisted of: ciprofloxacin from the beginning of the conditioning until neutrophil recovery; fluconazole until D+ 75; cotrimoxazole from neutrophil recovery until $\mathrm{T}$ CD4+ count recovery and acyclovir until $\mathrm{T}$ $\mathrm{CD} 4+$ count recovery. All patients received intravenous immunoglobulin to maintain $\mathrm{IgG}$ level over $500 \mathrm{mg} / \mathrm{dL}$. Blood samples from all patients were screened weekly by polymerase chain reaction (PCR) for cytomegalovirus (CMV), Epstein-Barr virus and adenovirus, as well as for Aspergillus antigen (galactomannan).

\section{RESULTS}

\section{Engraftment}

One patient died 20 days after transplant and was not evaluable for engraftment. Three patients did not engraft: 1 patient with SCID did not have lymphocyte recovery until 70 days post-transplant, 1 patient died at day +24 without neutrophil recovery and 1 patient with IPEX syndrome had an autologous recovery and underwent a second UCB transplantation 3 months later. He had full engraftment 14 days after transplant. The other three patients engrafted, with $100 \%$ donor chimerism (PCR-short tandem repeat (STR) on total leukocytes).

\section{Regimen related toxicity}

Three patients had sinusoidal obstruction syndrome of the liver, two of them severe and lethal, one moderate that responded to treatment with defibrotide. Only one patient developed acute grade II GVHD (skin and gut) that responded to steroids. None of the evaluable patients (alive 100 days after transplant) developed chronic GVHD. Two patients had bacterial sepsis that responded to antibiotics and volume replacement. Two patients had CMV reactivations detected by PCR, treated with foscarnet. One patient had Candida guilliermondi infection, which responded to liposomal amphotericin.

\section{Survival and causes of death}

Two patients with hyper-IgM syndrome and previous sclerosing cholangitis died at day +20 and $\mathrm{D}+24$ of sinusoidal obstruction syndrome of the liver. One patient with SCID died with acute distress respiratory syndrome due to alveolar proteinosis following parainfluenza infection. Four patients are alive and well from 60 to 452 days after transplant. The patient with IPEX syndrome had total recovery from all autoimmune manifestations, except for diabetes.

\section{Immune reconstitution}

One patient with SCID was at 60 days post-transplant and was not evaluable for immune reconstitution. Absolute numbers of total lymphocytes, $\mathrm{T} \mathrm{CD} 3+, \mathrm{T}$ CD4+ and T CD8+ cells were available for Patients 3 and 5 and are shown in figure 1 . Two patients (Patients 3 and 4) were still receiving immunoglobulin replacement therapy.

\section{DISCUSSION}

Severe PIDs are rare disorders that can be lethal early in life if untreated. In Brazil and other Latin American countries, public institutions and cooperative groups (Brazilian Group for Immunodeficiency/Latin American Group for Primary Immunodeficiencies - BRAGID/ LAGID) have been doing a great effort on educating physicians and the general public about the warning signs for PID diagnosis. For this reason, the frequency of PID diagnosis has increased in the last years ${ }^{(8)}$. In Brazil, the first transplant for a PID disease was made in Universidade Federal do Paraná (UFPR), Curitiba (PR), in 1992, in a patient with Wiskott-Aldrich syndrome. Since then, the number of transplants has increased, totalizing 76 transplants for PID diseases in Brazil until 2007 $7^{(9)}$.

In our institution, in 2008, we developed a program in collaboration with public institutions for the treatment of these patients with HSCT and we reported here our experience with these transplants. Seven patients received eight transplants for different PID diagnosis. 


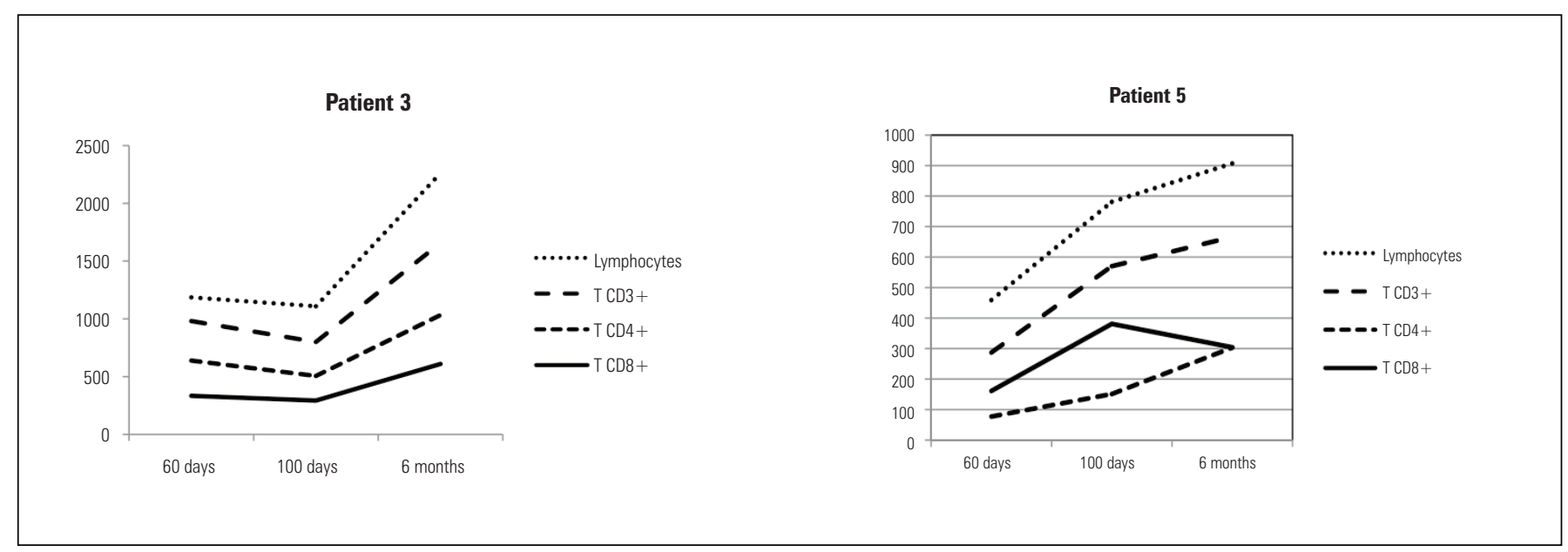

Figure 1. Immune reconstitution: total lymphocytes, T CD3+, T CD4+ and T CD8+ cells counts of Patients 3 and 5 at 60 days, 100 days and 6 months after transplantation

One of the most important prognostic factors for these transplants is related to patients' condition prior to $\mathrm{HSCT}^{(4)}$. Due to delayed diagnosis, all patients treated in our unit had or had had severe infectious episodes before being referred for treatment. The three patients who died from transplant-related causes had bad performance status at the moment of HSCT. This fact may have contributed for the less favorable outcomes of our patient series.

Since July 2010 we started a program in order to perform $\mathrm{Bu}$ dosing and pharmacokinetics. Bu levels present a large variability in children, leading sometimes to engraftment failure (underexposure) or increased toxicity (overexposure) ${ }^{(10)}$. Two patients in our series (Patients 5 and 7) benefited from this study and had their $\mathrm{Bu}$ area under the curve (AUC) measured. The use of $\mathrm{Bu}$ adapted for AUC levels may also contribute for further reduction of regimen-related toxicities.

\section{CONCLUSION}

The experience of our unit in the treatment of severe PID with HSCT was shown. The opportunity to offer this expensive and specialized treatment for patients from the public health system contributes to improve survival in these severe disorders. The nationwide effort of cooperative groups to improve PID diagnosis is mandatory to ameliorate the conditions of patients referred for transplantation, thus improving their survival and quality of life.

\section{REFERENCES}

1. Geha RS, Notarangelo LD, Casanova J-L, Chapel H, Conley ME, Fischer A, Hammarström L, Nonoyama S, Ochs HD, Puck JM, Roifman C, Seger R, Wedgwood J; International Union of Immunological Societies
Primary Immunodeficiency Diseases Classification Committee. Primary immunodeficiency diseases: An update from the International Union of Immunological Societies Primary Immunodeficiency Diseases Classification Committee. J Allergy Clin Immunol. 2007;120(4):776-94

2. Gatti RA, Meuwissen HJ, Allen HD, Hong R, Good RA. Immunological reconstitution of sex-linked lymphopenic immunological deficiency. Lancet. 1968;2(7583):1366-9.

3. Bach FH, Albertini RJ, Joo P, Anderson JL, Bortin MD. Bone marrow transplantation in a patient with the Wiskott-Aldrich syndrome. Lancet. 1968;2(7583):1364-6.

4. Antoine C, Muller S, Cant A, Cavazzana-Calvo M, Veys P, Vossen J, Fasth A, Heilmann C, Wulffraat N, Seger R, Blanche S, Friedrich W, Abinun M, Davies G, Bredius R, Schulz A, Landais P, Fischer A; European Group for Blood and Marrow Transplantation; European Society for Immunodeficiency. Long-term survival and transplantation of haemopoietic stem cells for immunodeficiencies: report of the European experience 1968-99. Lancet. 2003;361 (9357):553-60.

5. Grunebaum E, Mazzolari E, Porta F, Dallera D, Atkinson A, Reid B, et al. Bone marrow transplantation for severe combined immune deficiency. JAMA. 2006;295(5):508-18.

6. Bhattacharya A, Slatter M, Chapman C, Barge D, Jackson A, Flood T, et al. Single centre experience of umbilical cord stem cell transplantation for primary immunodeficiency. Bone Marrow Transplant. 2005;36(4):295-9.

7. Haddad E, Landais P, Friedrich W, Gerritsen B, Cavazzana-Calvo M, Morgan $\mathrm{G}$, et al. Long-term immune reconstitution and outcome after HLAnonidentical T-cell-depleted bone marrow transplantation for severe combined immunodeficiency: a European retrospective study of 116 patients. Blood. 1998;91(10):3646-53.

8. Leiva LE, Zelazco M, Oleastro M, Carneiro-Sampaio M, Condino-Neto A, CostaCarvalho BT, Grumach AS, Quezada A, Patiño P, Franco JL, Porras 0, Rodríguez FJ, Espinosa-Rosales FJ, Espinosa-Padilla SE, Almillategui D, Martínez C, Tafur JR, Valentín M, Benarroch L, Barroso R, Sorensen RU; Latin American Group for Primary Immunodeficiency Diseases. Primary immunodeficiency diseases in Latin America: The second report of the LAGID Registry. J Clin Immunol. 2007;27(1):101-8.

9. Bonfim C, Bittencourt H, Rodrigues CA, Rocha V. Transplante de células-tronco hematopoiéticas para doenças hereditárias:imunodeficiências primárias. Doenças de depósito e hemoglobinopatias. In: Voltarelli JC, Pasquini R, Ortega ETT. Transplante de células-tronco hematopoiéticas. São Paulo: Atheneu; 2009. p.421-53.

10. Bartelink IH, Bredius RGM, Belitser SV, Suttorp MM, Bierings M, Knibbe $\mathrm{CAJ}$, et al. Association between busulfan exposure and outcome in children receiving intravenous busulfan before hematologic stem cell transplantation. Biol Blood Marrow Transplant. 2009;15(2):231-41. 